\title{
Antiparasitic activity of the essential oil of Lippia alba on ectoparasites of Colossoma macropomum (tambaqui) and its physiological and histopathological effects
}

\author{
Bruna Viana Soares ${ }^{\mathrm{a}}$, Lígia Rigôr Neves ${ }^{\mathrm{b}}$, Marcos Sidney Brito Oliveira ${ }^{\mathrm{c}}$, Francisco Célio Maia Chaves ${ }^{\mathrm{d}}$, \\ Márcia Kelly Reis Dias a , Edsandra Campos Chagas ${ }^{\mathrm{d}}$, Marcos Tavares-Dias ${ }^{\mathrm{a}, \mathrm{b}, *}$ \\ a Postgraduate Program on Tropical Biodiversity (PPGBIO), Federal University of Amapá (UNIFAP), Macapá, AP, Brazil \\ b Laboratory for Aquatic Organism Health, Embrapa Amapá, Macapá, AP, Brazil \\ c Postgraduate Program on Amazon Basin Aquatic Resources (PPG-RACAM), University of the West of Pará (UFOPA), Santarém, PA, Brazil \\ d Embrapa Western Amazon, Manaus, AM, Brazil
}

\section{A R T I C L E I N F O}

\section{Article history:}

Received 3 September 2015

Received in revised form 22 October 2015

Accepted 23 October 2015

Available online 24 October 2015

\section{Keywords:}

Monogenoideans

Parasites

Medicinal plant

Blood

Tambaqui

\begin{abstract}
A B S T R A C T
This study investigated the in vivo and in vitro antiparasitic effects of the essential oil of Lippia alba and the bloodrelated and histopathological alterations that it causes in Colossoma macropomum. In the in vitro trial, the anthelminthic effects of 160,320,640, 1280 and $2560 \mathrm{mg} / \mathrm{L}$ of the essential oil were tested against monogenoideans (Anacanthorus spathulatus, Notozothecium janauachensis and Mymarothecium boegeri) of the gills of this fish, which are its natural parasites. The concentrations of $1280 \mathrm{mg} / \mathrm{L}$ and $2560 \mathrm{mg} / \mathrm{L}$ showed $100 \%$ efficacy after $20 \mathrm{~min}$ of exposure to the essential oil, while at lower concentrations this efficacy against the gill monogenoideans only occurred after $2-3 \mathrm{~h}$ of in vitro exposure. However, in the controls, mortality of all of these monogenoideans only occurred after $9 \mathrm{~h}$. A total of 240 fry were distributed into four treatments (20 fish per repetition) and three repetitions were used in the in vivo trial for baths with 100 and $150 \mathrm{mg} / \mathrm{L}$ of the essential oil of L. alba, for 30 min. The efficacy in this trial against Ichthyophthirius multifiliis in fish exposed to 100 and $150 \mathrm{mg} / \mathrm{L}$ of the essential oil was $40.7 \%$ and $50.3 \%$, respectively. However, for monogenoideans, there was efficacy of $14.0 \%$ only in the fish exposed to $100 \mathrm{mg} / \mathrm{L}$ of the essential oil used. Moreover, the fish exposed to these concentrations of the essential oil presented increased plasma glucose levels, thus denoting signs of stress. Severe lesions such as hyperplasia, fusion of the lamellar epithelium, capillary dilatation, epithelial detachment, lamellar aneurysm, epithelial rupture with hemorrhage, congestion, edema, necrosis, mucous cell proliferation, chloride cells and lamellar hypertrophy were observed in the gills of the fish exposed to 100 and $150 \mathrm{mg} / \mathrm{L}$ of the essential oil of $L$. alba. Alterations to total protein levels, hemoglobin, hematocrit, red blood cell number, thrombocytes number, white blood cell number, lymphocytes, eosinophils and blood neutrophil number was also observed in these fish. The essential oil of $L$. alba showed great potential for antiparasitic treatment, given that it had high in vitro efficacy against monogenoideans and in vivo efficacy against the protozoon $I$. multifilis. Because of the low concentrations of the essential oil (100 and $150 \mathrm{mg} / \mathrm{L})$ that were tolerated by the fish and thus could be used in the therapeutic baths, the efficacy against monogenoideans was low. This indicates that there is a need for additional strategies for using this essential oil in antiparasitic treatments, since the concentrations that eliminate these ectoparasites are toxic for the hosts. Lastly, this was the first study on the antiparasitic activity of $L$. alba.

Statement of Relevance The manuscript entitled "Antiparasitic activity of the essential oil of Lippia alba on ectoparasites of Colossoma macropomum (tambaqui) and its physiological and histopathological effects", represents original article on use of the essential oil of Lippia alba on ectoparasites of tambaqui, an important finfish of Amazon region. This manuscript includes treatment in vitro against monogeneans, and in vivo against protozoans and monogeneans, besides histopathological and hematological features of the fish exposed to different concentrations of L. alba, a medical plant from South and Central America.
\end{abstract}

(c) 2015 Elsevier B.V. All rights reserved.
* Corresponding author at: Embrapa Amapá, Rodovia Juscelino Kubitschek, km 5, 2600 68903-419 Macapá, AP, Brazil.

E-mail address: marcos.tavares@embrapa.br (M. Tavares-Dias).

\section{Introduction}

Phytotherapy has become an important alternative in treatments for parasitic diseases, given the secondary effects that are attributed to 
synthetic drugs. Medicinal plants may contain one or more chemical compounds with potential for therapeutic use. Lippia alba (Mill.) Brown (Verbenaceae) is a small aromatic bush that is widespread in many regions of the world, such as Brazil, Bangladesh, India, Mexico, Paraguay, Uruguay, northern Argentina, southern United States and Australia.

Because of the great bioactive potential of $L$. alba, with analgesic, anti-inflammatory, sedative and anti-spasmodic effects, it is greatly used in traditional medicine (Mamun-Or-Rashid et al., 2013; Tavares et al., 2011). Studies have proven that the essential oil of $L$. alba and its constituents have the following types of activity: antibacterial, antifungal and antiprotozoal (Fabri et al., 2011; Nogueira et al., 2007; Oliveira et al., 2006), antiparasitic (Escobar et al., 2010) and anti-inflammatory (Haldar et al., 2012). In fish subjected to transportation, the essential oil of $L$. alba has been shown to have anesthetic action and to reduce the levels of oxidative stress (Azambuja et al., 2011, Cunha et al., 2010). These bioactive properties of the essential oil of $L$. alba are attributed to the richness of its major chemical constituents, such as geranial, carvone, neral, linalool and limonene. Recently, use of natural products derived from plants, for controlling parasites, has received great attention (Boijink et al., 2015; Hashimoto et al., 2016; Huang et al., 2013; Ji et al., 2012; Steverding et al., 2005; Xiao-Feng et al., 2014; Zhang et al., 2013; Zhang et al., 2014; Zheng et al., 2015). However, the effects of the essential oil of $L$. alba on ectoparasites of fish have not been investigated.

Colossoma macropomum Cuvier, 1818, commonly maned tambaqui, is a member of the family Serassalmidae living in the Amazon region and is widely farmed in different intensive systems because of its good adaptation to balanced feed and relatively unspecialized characteristics. However, with increasing production of this Amazonian fish, parasitic diseases caused by ectoparasites, protozoa Ichthyophthirius multifiliis Fouquet, 1876; monogenoideans Anacanthorus spathulatus; Notozothecium janauachensis, Mymarothecium boegeri Cohen \& Kohn and Linguadactyloides brinkmanni have emerged and affected its farming, thus giving rise to economic losses due to epizooties (Boijink et al., 2015; Pinheiro et al., 2015). These problems require a constant monitoring in order to diagnose and adequately treat the parasitic diseases, and this is a challenge in relation to intensive farming of tambaquis. However, the substances used for controlling these parasites are chemotherapeutic products that are generally toxic to fish and may also cause damage to human health and to the environment (Pinheiro et al., 2015). Use of natural products with therapeutic properties, such as the essential oil of L. alba, may provide a solution for controlling these parasites in fish.

Thus, studies to test their efficacy, which has not yet been investigated, are required. This present study had the aim to investigate the in vivo and in vitro antiparasitic effects of the essential oil of $L$. alba and the blood-related and histopathological alterations that it causes in the gills of tambaqui (C. macropomum).

\section{Materials and methods}

\subsection{Obtainment of essential oil of L. alba and its chemical composition}

The plants were cultivated and the essential oil was extracted in the Medicinal Plants and Vegetables Sector of Embrapa Western Amazon, in Manaus, state of Amazonas (Brazil). The essential oil was extracted from the leaves and inflorescences of $L$. alba (three years of age) through hydrodistillation in Clevenger apparatus. The chemical analysis on the essential oils was done by means of gas chromatography with mass spectrometry and details can be found in Hashimoto et al. (2016). The chemical components of the essential oil of $L$. alba used in this study are shown in Table 1.

\subsection{Fish and acclimation}

The experiments were conducted at the Aquaculture and Fishery Laboratory of Embrapa Amapá, Macapá, state of Amapá (Brazil). Fry of
Table 1

Chemical constituents of the essential oil of Lippia alba.

\begin{tabular}{cccl}
\hline Peak & \% content & Retention index (RI) & Identification \\
\hline 1 & 0.7 & 977 & Beta-Pinene \\
2 & 3.5 & 989 & Myrcene \\
3 & 17.5 & 1029 & Limonene \\
4 & 0.3 & 1037 & $(Z)$-Ocimene \\
5 & 1.1 & 1048 & $(E)$-Ocimeno \\
6 & 1.6 & 1096 & Linalool \\
7 & 0.2 & 1200 & Trans-Dihydrocarvone \\
8 & 0.4 & 1216 & Trans-Carveol \\
9 & 61.7 & 1245 & Carvone \\
10 & 0.6 & 1252 & Piperitone \\
11 & 0.7 & 1337 & Piperitenone \\
12 & 0.5 & 1372 & Alpha-Copaene \\
13 & 0.4 & 1380 & Beta-Bourbonene \\
14 & 0.3 & 1387 & Beta-Elemene \\
15 & 1.8 & 1414 & $(E)$-Beta-Caryophyllene \\
16 & 0.2 & 1456 & Alpha-Humulene \\
17 & 2.7 & 1475 & Germacrene D \\
18 & 0.2 & 1497 & Alpha-Muurolene \\
19 & 0.5 & 1508 & Germacrene A \\
20 & 0.4 & 1517 & Gamma-Cadinene \\
21 & 0.4 & 1557 & Nerolidol \\
22 & 0.3 & 1576 & Caryophyllene Oxide \\
23 & 0.8 & 1641 & Beta-Cedren-9-One \\
24 & 3.0 & 1655 & Unterminated \\
25 & 0.4 & 1677 & Unterminated \\
Total identified $\%$ : & & & \\
\hline & & & \\
\hline
\end{tabular}

C. macropomum were obtained from commercial fish farms for in vitro and in vivo trials. These fish were acclimated for seven days in $500 \mathrm{~L}$ water tanks and were fed with fish food containing 32\% crude protein. A system of constant water recirculation was maintained in the tanks and the water parameters were monitored. The mean values were: temperature $30.4 \pm 0.1{ }^{\circ} \mathrm{C}$; dissolved oxygen $5.5 \pm 0.2 \mathrm{mg} / \mathrm{L}$; pH $5.3 \pm 0.2$; ammonium $0.5 \pm 0.2 \mathrm{mg} / \mathrm{L}$; alkalinity $10.0 \pm 0 \mathrm{mg} / \mathrm{L}$; and hardness $10.0 \pm 0 \mathrm{mg} / \mathrm{L}$. The organic matter that accumulated at the bottoms of the tanks was removed once a day. This study was developed in accordance with the principles adopted by the Brazilian College of Animal Experimentation (COBEA).

\subsection{In vitro trial using essential oil of L. alba and monogenoideans of C. macropomum}

To evaluate the length of exposure to and concentrations of the essential oil of $L$. alba that caused mortality among monogenoideans species in the gills of 20 fish $(12.0 \pm 3.0 \mathrm{~cm}$ and $35.0 \pm 25.0 \mathrm{~g})$, in vitro tests were conducted. For this trial, two control groups were used: one with tank water and the other with tank water plus absolute ethyl alcohol; and five different concentrations of the essential oil of L. alba (160, 320, 640, 1280 and $2560 \mathrm{mg} / \mathrm{L})$, using three repetitions for each treatment. This solvent was used in the proportions of 1/10.

Fish gill arches that were naturally parasitized by monogenoideans were removed and placed individually in Petri dishes, in which they were immersed in solutions of the essential oil of $L$. alba $(160,320$, 640,1280 or $2560 \mathrm{mg} / \mathrm{L}$ ). Using a stereomicroscope, fields of view containing a minimum of 20 monogenoideans were selected for each repetition. After the gill arches had been immersed in different concentrations of the essential oil of $L$. alba, these were viewed every 10 min to quantify the numbers of live and dead monogenoideans. Parasites were considered to be dead if they detached from the tissue or, while still attached, had totally lost their mobility (Hashimoto et al., 2016). Following this, the efficacy of each treatment was calculated (Zhang et al., 2014).

From the in vitro results, the concentrations used in the therapeutic baths with the essential oil of L. alba were determined, after conducting a tolerance test on the fish. 


\subsection{In vivo trial on C. macropomum}

Naturally parasitized fry $(11.0 \pm 1.0 \mathrm{~cm}$ and $44.0 \pm 10.0 \mathrm{~g})$, obtained of a fish farm, were distributed randomly into twelve $100 \mathrm{~L}$ tanks and were kept in an open water system for $48 \mathrm{~h}$. For this trial, four treatments and three repetitions were used, with 20 fish per repetition, and the fish were maintained in a static water system (mean temperature $29.3 \pm 0.1{ }^{\circ} \mathrm{C}$; dissolved oxygen $6.3 \pm 0.06 \mathrm{mg} / \mathrm{L} ; \mathrm{pH} 5.2 \pm 0.09$; ammonia $0.3 \pm 0.12 \mathrm{mg} / \mathrm{L}$; alkalinity $10.0 \pm 0 \mathrm{mg} / \mathrm{L}$; and hardness $10.0 \pm 0 \mathrm{mg} / \mathrm{L}$ ), using a multiparameter portable Hanna HI9829®. The treatments were as follows: control groups with tank water or with tank water plus absolute ethyl alcohol $(1 / 10)$; the solvent used for dilution of the essential oil; and 100 and $150 \mathrm{mg} / \mathrm{L}$ of the essential oil of $L$. alba. The fish of all the treatments were exposed to the essential oil of $L$. alba for $30 \mathrm{~min}$, except for those in the control groups. After the 30 -min bath, the tank water was kept under continuous flow. Ten fish from each repetition of the different treatments were used for collection of the gills, which were then fixed in 5\% formalin in order to collect, quantify and identify the parasites. The parasites were prepared for identification using previous recommendations (Eiras et al., 2006) and identified according to Cohen et al. (2013). After the parasites had been quantified, the prevalence and mean intensity of infection were calculated (Bush et al., 1997). The efficacy of each treatment was also calculated (Zhang et al., 2014). The other fish sample was used for the blood tests and histopathological analyses.

The in vitro concentrations that were previously tested showed that the fish had low tolerance to the essential oil of $L$. alba. Therefore, only the concentrations of 100 and $150 \mathrm{mg} / \mathrm{L}$ could be used in the therapeutic baths.

\subsection{Analysis procedures on the blood parameters of C. macropomum}

After the 30-min therapeutic baths with 0,100 and $150 \mathrm{mg} / \mathrm{L}$ of the essential oil of $L$. alba had been conducted, five fish from each repetition (15 fish per treatment) were used for blood collection. From each of these fish, a blood sample was collected by means of puncturing the caudal vessel, using syringes containing ethylenediamine tetraacetic acid (EDTA 10\%), and these samples were divided into two aliquots. One aliquot was used to determine the red blood cell (RBC) counts in a hemocytometer, hematocrit using the microhematocrit method and hemoglobin concentration using the cyanmethemoglobin method. These data were used to calculate the Wintrobe hematimetric indices: mean corpuscular volume (MCV) and mean corpuscular hemoglobin concentration (MCHC). Blood extensions were prepared and stained panchromatically using a May-Grünwald-Giemsa-Wright combination (Ranzani-Paiva et al., 2013) in order to make differential white blood cell counts in up to 200 cells of interest in each extension. The white blood cell populations were identified and named in accordance with the recommendations of Tavares-Dias et al. (1999). The extensions were also used to count the total numbers of total white blood cells (WBC) and total thrombocytes (Ranzani-Paiva et al., 2013).

The second aliquot of the blood samples was centrifuged at $75 \mathrm{~g}$, in order to obtain plasma and analyze the total plasma glucose and protein levels. The glucose concentration was determined by means of the glucose oxidase enzymatic-colorimetric method, using a commercial kit (Biotécnica, MG, Brazil). The total plasma protein concentration was determined by means of the biuret method, using a commercial kit (Biotécnica, MG, Brazil). For both of these biochemical analyses, the readings were made using a spectrophotometer Biospectro SP-220®.

\subsection{Histopathological analysis procedures on the gills of $C$. macropomum}

After the 30 -min therapeutic baths using 0,100 and $150 \mathrm{mg} / \mathrm{L}$ of the essential oil of $L$. alba had been conducted, six fish per treatment (two fish from each repetition) were used to collect gill arches for histopathological analyses. $24 \mathrm{~h}$ after these therapeutic baths, another six fish per treatment (two fish from each repetition) were used to collect gill arches for histopathological analyses (recovery). These fish that were used in relation to recovery had been kept in the tanks with a continuous water flow and had been fed.

The first right-side gill arch from each fish was collected and fixed in buffered formalin (10\%), for histopathological analyses. The gill arches were dehydrated through a graded series ethanol and xylol baths and were then embedded in paraffin in order to obtain consecutive serial sections using a microtome. The histological sections were stained with hematoxylin and eosin (HE) and were analyzed under an ordinary optical microscope.

The histopathological analysis was performed semiquantitatively using the mean assessment values (MAV) (Schwaiger et al., 1997) and the histopathological alteration index (HAI) (Poleksic and MitrovicTutundzic, 1994).

\subsection{Statistical analysis}

All the data were initially assessed with regard to the assumptions of normal distribution and homoscedasticity, using the Shapiro-Wilk and Bartlett tests, respectively. For the data with normal distribution, analysis of variance (ANOVA) was used, followed by the Dunn test, to make comparisons between the means. For the data that did not follow this

Table 2

In vitro antiparasitic action of the essential oil of Lippia alba against monogenoideans of Colossoma macropomum, in relation to the concentration and time of exposure.

\begin{tabular}{|c|c|c|c|}
\hline Time (hours) & Treatments & No. of live parasites & No. of dead parasites \\
\hline \multirow{12}{*}{$0 \mathrm{~h}$} & Water & 76 & 0 \\
\hline & Water + alcohol & 66 & 0 \\
\hline & $160 \mathrm{mg} / \mathrm{L}$ & 70 & 0 \\
\hline & $320 \mathrm{mg} / \mathrm{L}$ & 65 & 0 \\
\hline & $640 \mathrm{mg} / \mathrm{L}$ & 60 & 0 \\
\hline & $1280 \mathrm{mg} / \mathrm{L}$ & 75 & 0 \\
\hline & $2560 \mathrm{mg} / \mathrm{L}$ & 74 & 0 \\
\hline & Water & 76 & 0 \\
\hline & Water + alcohol & 66 & 0 \\
\hline & $160 \mathrm{mg} / \mathrm{L}$ & 70 & 0 \\
\hline & $320 \mathrm{mg} / \mathrm{L}$ & 65 & 0 \\
\hline & $640 \mathrm{mg} / \mathrm{L}$ & 20 & 40 \\
\hline \multirow{8}{*}{$1 \mathrm{~h}$} & $1280 \mathrm{mg} / \mathrm{L}$ & 0 & 75 \\
\hline & $2560 \mathrm{mg} / \mathrm{L}$ & 0 & 74 \\
\hline & Water & 76 & 0 \\
\hline & Water + alcohol & 63 & 3 \\
\hline & $160 \mathrm{mg} / \mathrm{L}$ & 66 & 4 \\
\hline & $320 \mathrm{mg} / \mathrm{L}$ & 0 & 65 \\
\hline & $640 \mathrm{mg} / \mathrm{L}$ & 0 & 60 \\
\hline & $1280 \mathrm{mg} / \mathrm{L}$ & 0 & 75 \\
\hline \multirow[t]{7}{*}{$2 \mathrm{~h}$} & $2560 \mathrm{mg} / \mathrm{L}$ & 0 & 74 \\
\hline & Water & 76 & 0 \\
\hline & Water + alcohol & 60 & 6 \\
\hline & $160 \mathrm{mg} / \mathrm{L}$ & 0 & 70 \\
\hline & 320 mg/L & 0 & 65 \\
\hline & $640 \mathrm{mg} / \mathrm{L}$ & 0 & 60 \\
\hline & $1280 \mathrm{mg} / \mathrm{L}$ & 0 & 75 \\
\hline \multirow[t]{7}{*}{$3 \mathrm{~h}$} & $2560 \mathrm{mg} / \mathrm{L}$ & 0 & 74 \\
\hline & Water & 8 & 68 \\
\hline & Water + alcohol & 30 & 36 \\
\hline & $160 \mathrm{mg} / \mathrm{L}$ & 0 & 70 \\
\hline & $320 \mathrm{mg} / \mathrm{L}$ & 0 & 65 \\
\hline & $640 \mathrm{mg} / \mathrm{L}$ & 0 & 60 \\
\hline & $1280 \mathrm{mg} / \mathrm{L}$ & 0 & 75 \\
\hline \multirow[t]{7}{*}{$6 \mathrm{~h}$} & $2560 \mathrm{mg} / \mathrm{L}$ & 0 & 74 \\
\hline & Water & 0 & 76 \\
\hline & Water + alcohol & 0 & 66 \\
\hline & $160 \mathrm{mg} / \mathrm{L}$ & 0 & 70 \\
\hline & $320 \mathrm{mg} / \mathrm{L}$ & 0 & 65 \\
\hline & $640 \mathrm{mg} / \mathrm{L}$ & 0 & 60 \\
\hline & $1280 \mathrm{mg} / \mathrm{L}$ & 0 & 75 \\
\hline $9 \mathrm{~h}$ & $2560 \mathrm{mg} / \mathrm{L}$ & 0 & 74 \\
\hline
\end{tabular}




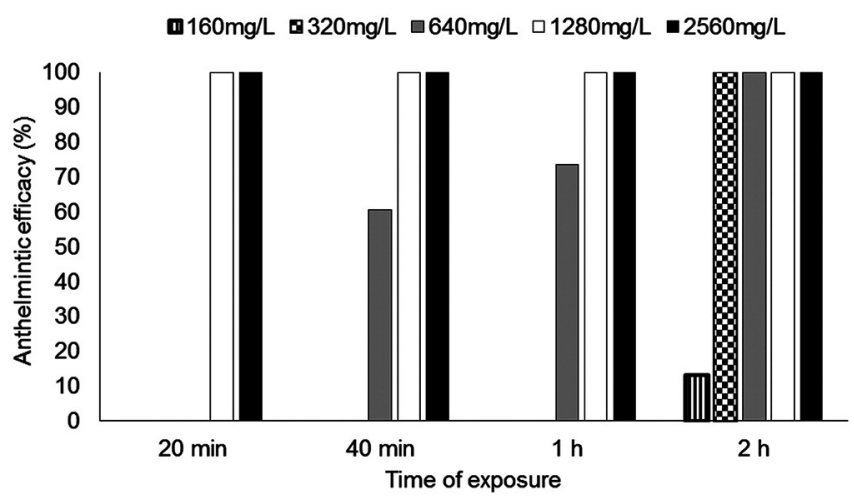

Fig. 1. In vitro efficacy of different concentrations of the essential oil of Lippia alba against monogenoideans in Colossoma macropomum.

distribution pattern, the Kruskal-Wallis test was used, followed by the Tukey test, to make comparisons between the medians $(\mathrm{p}<0.05)$.

\section{Results}

\subsection{In vitro antiparasitic action of the essential oil of $L$. alba}

In the in vitro tests, the essential oil of $L$. alba was shown to have $100 \%$ anthelmintic activity against the monogenoideans $A$. spathulatus, $N$. janauachensis and $M$. boegeri on the gills of $C$. macropomum, after $20 \mathrm{~min}$ of exposure at the concentrations of $1280 \mathrm{mg} / \mathrm{L}$ and $2560 \mathrm{mg} / \mathrm{L}$, i.e. the time at which the parasites were seen to have become immobilized. At the concentrations of 320 and $640 \mathrm{mg} / \mathrm{L}$, total immobilization of the parasites only occurred after $2 \mathrm{~h}$ of in vitro exposure. At the lowest concentration $(160 \mathrm{mg} / \mathrm{L})$, this occurred after $3 \mathrm{~h}$ of exposure. In comparison, the beginning of mortality among the monogenoideans of water + alcohol control was observed after $2 \mathrm{~h}$, while in water control group, this occurred after $6 \mathrm{~h}$ of exposure. Total immobilization of the parasites in these two control groups occurred after 9 h (Table 2 and Fig. 1).

\subsection{In vivo antiparasitic action (therapeutic baths)}

The gills of all the fish exposed to the essential oil of $L$. alba were naturally parasitized by I. multifilis, A. spathulatus, M. boegeri and $N$. janauachensis, with variations in abundance between the different treatments. After the 30-min therapeutic baths, the concentrations of 100 and $150 \mathrm{mg} / \mathrm{L}$ of the essential oil of $L$. alba were found to have reduced the abundance ( $\mathrm{p}<0.001$ ) of I. multifiliis, but the lower concentration had an effect on the abundance of these three species of monogenoideans. However, the water + alcohol group also had efficacy of $29.1 \%$ on the abundance of these ectoparasites (Table 3 ).

In the therapeutic baths, the fish presented static behavior, such that they remained submersed at the bottom of the tanks, thus making it impossible to use baths of more than $30 \mathrm{~min}$. However, the fish in the control groups, which were exposed to water or to water + alcohol, did not present this behavior. With the return of the continuous water flow in the tanks, in order to eliminate the essential oil, the fish that had been exposed to this oil rapidly resumed swimming. There was no mortality either during or after the experiment.

\subsection{Effects of therapeutic baths with L. alba on blood parameters}

Thirty-min baths with 100 or $150 \mathrm{mg} / \mathrm{L}$ of the essential oil of L. alba increased the plasma glucose levels of $C$. macropomum, including in group tested with water + alcohol. The total protein levels only increased $(\mathrm{p}<0.05)$ in the fish exposed to $150 \mathrm{mg} / \mathrm{L}$. The hemoglobin, hematocrit and total RBC number were similar $(p>0.05)$ in the two control groups with water and water + alcohol, but the hemoglobin level in group fish with water + alcohol was greater than the levels in the two groups exposed to the essential oil of $L$. alba. However, the hematocrit and RBC number in fish exposed to 100 and $150 \mathrm{mg} / \mathrm{L}$ were lower $(\mathrm{p}<0.05$ ) than observed in fish exposed only to water, while the MCHC and thrombocytes number were higher. WBC, lymphocyte and eosinophil number were lower $(p<0.05)$ than in both control groups, while there was a higher neutrophil level $(p<0.05)$ in the group exposed to $150 \mathrm{mg} / \mathrm{L}$ of the essential oil of $L$. alba (Table 4 ).

\subsection{Histopathological effects on the gills after therapeutic baths with L. alba}

In the gills of $C$. macropomum, after the 30-min therapeutic baths, there was no difference in MAV between any of the treatments and the controls with water and water + alcohol. However, after this bath there were changes in feeding behavior of the fish, because only some fish eat. In addition, after $24 \mathrm{~h}$ of recovery, there were increases in values of fish exposed to water + alcohol and in the groups exposed to 100 or $150 \mathrm{mg} / \mathrm{L}$ of the essential oil of L. alba. After the 30-min bath, increased HAI values $(p<0.05)$ in fish exposed to 100 or $150 \mathrm{mg} / \mathrm{L}$ of the essential oil of $L$. alba were found when compared to the fish exposed only to water. Similarly, after $24 \mathrm{~h}$ of recovery, increased HAI values $(\mathrm{p}<0.05)$ in fish exposed to 100 or $150 \mathrm{mg} / \mathrm{L}$ of the essential oil of $L$. alba in those exposed to water + alcohol were observed compared to fish exposed only to water (Table 5). These changes in MAV and HAI were due to severe damage in gills of the fish exposed to the essential oil of L. alba, such as hyperplasia, fusion of the lamellar epithelium, capillary dilatation, detachment of the lamellar epithelium, lamellar aneurysm, epithelial rupture with hemorrhage, congestion, edema and necrosis (Fig. 2), along with proliferation of mucous cells and chloride cells and lamellar hypertrophy occurred in lower frequency.

\section{Discussion}

Fish farming is an important economic activity in Brazil, and it has increased considerably over the last decade. However, low environmental quality has given rise to high losses for this industry that have not yet been quantified, due to diseases in fish caused by monogenean and protozoan ectoparasites (Boijink et al., 2015; Hashimoto et al., 2016; Martins et al., 2002; Pinheiro et al., 2015). The main strategies for controlling and treating these ectoparasites generally involve chemotherapy, but its constant and erroneous use has led to reduced antiparasitic effectiveness. In addition, the chemical products involved cause death among fish because of their toxicity (Boijink et al., 2015; Steverding et al., 2005; Zhang et al., 2013; Zhang et al., 2014). Thus, many researchers' attention has been drawn towards seeking natural

Table 3

Prevalence (P\%) and mean abundance (MA) of the gill parasites in Colossoma macropomum exposed to the essential oil of Lippia alba.

\begin{tabular}{|c|c|c|c|c|c|c|c|c|}
\hline \multirow[b]{2}{*}{ Parasite species } & \multicolumn{2}{|c|}{ Water $(\mathrm{n}=30)$} & \multicolumn{2}{|c|}{ Water + alcohol $(\mathrm{n}=30)$} & \multicolumn{2}{|c|}{$100 \mathrm{mg} / \mathrm{L}(\mathrm{n}=30)$} & \multicolumn{2}{|c|}{$150 \mathrm{mg} / \mathrm{L}(\mathrm{n}=30)$} \\
\hline & $\mathrm{P}(\%)$ & MA & $\mathrm{P}(\%)$ & MA & $\mathrm{P}(\%)$ & MA & $\mathrm{P}(\%)$ & MA \\
\hline Ichthyophthirius multifiliis & 100 & $9607.8 \pm 4425.5^{\mathrm{a}}$ & 100 & $6813.3 \pm 2760.5^{\mathrm{ac}}$ & 100 & $5693.8 \pm 2256.7^{\mathrm{bc}}$ & 100 & $4777.3 \pm 1976.6^{\mathrm{b}}$ \\
\hline Anacanthorus spathulatus & 100 & $279.5 \pm 102.5^{\mathrm{b}}$ & 100 & $256.8 \pm 94.3^{\mathrm{a}}$ & 100 & $177.1 \pm 44.5^{\mathrm{c}}$ & 100 & $320.3 \pm 136.8^{\mathrm{a}}$ \\
\hline Mymarothecium boegeri & 100 & $11.3 \pm 6.9^{\mathrm{b}}$ & 70.4 & $3.9 \pm 4.7^{\mathrm{a}}$ & 73.3 & $2.9 \pm 2.9^{\mathrm{a}}$ & 83.3 & $4.0 \pm 4.6^{\mathrm{a}}$ \\
\hline Notozothecium janauachensis & 100 & $194.2 \pm 95.7^{b}$ & 100 & $159 \pm 99.9^{c}$ & 100 & $143.0 \pm 53.2^{\mathrm{a}}$ & 100 & $223.0 \pm 139.3^{\mathrm{a}}$ \\
\hline
\end{tabular}

Different letters on the same line indicate differences according to the Dunn test $(\mathrm{p}<0.001)$. 
Table 4

Blood parameters of Colossoma macropomum exposed to the essential oil of Lippia alba.

\begin{tabular}{|c|c|c|c|c|}
\hline Parameters & $\begin{array}{l}\text { Water } \\
(\mathrm{n}=15)\end{array}$ & $\begin{array}{l}\text { Water + alcohol } \\
(\mathrm{n}=15)\end{array}$ & $\begin{array}{l}100 \mathrm{mg} / \mathrm{L} \\
(\mathrm{n}=15)\end{array}$ & $\begin{array}{l}150 \mathrm{mg} / \mathrm{L} \\
(\mathrm{n}=15)\end{array}$ \\
\hline Glucose $(\mathrm{g} / \mathrm{dL})$ & $78.2 \pm 17.2^{\mathrm{b}}$ & $103.0 \pm 25.0^{\mathrm{a}}$ & $112.2 \pm 13.6^{\mathrm{a}}$ & $106.6 \pm 8.9^{\mathrm{a}}$ \\
\hline Proteins (mg/dL) & $2.5 \pm 0.7^{\mathrm{a}}$ & $2.7 \pm 0.9^{\mathrm{a}}$ & $2.5 \pm 0.2^{\mathrm{a}}$ & $3.0 \pm 0.3^{b}$ \\
\hline Hemoglobin $(\mathrm{g} / \mathrm{dL})$ & $6.8 \pm 0.7^{\mathrm{ab}}$ & $7.3 \pm 0.9^{b}$ & $6.1 \pm 0.9^{a}$ & $6.3 \pm 1.1^{\mathrm{a}}$ \\
\hline Hematocrit (\%) & $21.9 \pm 2.3^{\mathrm{a}}$ & $21.9 \pm 2.4^{\mathrm{a}}$ & $17.7 \pm 1.5^{\mathrm{b}}$ & $17.9 \pm 1.9^{\mathrm{b}}$ \\
\hline $\operatorname{RBCs}\left(\times 10^{6} / \mu \mathrm{L}\right)$ & $1.40 \pm 0.40^{\mathrm{a}}$ & $1.20 \pm 0.03^{\mathrm{ab}}$ & $1.00 \pm 0.30^{\mathrm{b}}$ & $1.00 \pm 0.30^{\mathrm{b}}$ \\
\hline $\mathrm{MCV}(\mathrm{fL})$ & $170.2 \pm 49.1^{\mathrm{a}}$ & $190.7 \pm 59.6^{\mathrm{a}}$ & $186.5 \pm 51.4^{\mathrm{a}}$ & $187.5 \pm 39.6^{\mathrm{a}}$ \\
\hline $\mathrm{MCHC}(\mathrm{g} / \mathrm{dL})$ & $31.2 \pm 4.1^{\mathrm{a}}$ & $33.5 \pm 5.9^{\mathrm{ab}}$ & $34.7 \pm 5.2^{\mathrm{b}}$ & $35.3 \pm 5.2^{\mathrm{b}}$ \\
\hline Thrombocytes $(\mu \mathrm{L})$ & $15,739 \pm 4626^{a}$ & $24,373 \pm 5460^{\mathrm{b}}$ & $20,035 \pm 5927^{b}$ & $19,556.3 \pm 5922.2^{\mathrm{ab}}$ \\
\hline $\mathrm{WBC}(\mu \mathrm{L})$ & $15,024 \pm 4414^{\mathrm{a}}$ & $10,968 \pm 2457^{b}$ & $6944 \pm 2540^{c}$ & $7709 \pm 2323^{c}$ \\
\hline Lymphocytes $(\mu \mathrm{L})$ & $10,435 \pm 3823^{a}$ & $5980 \pm 2907^{\mathrm{b}}$ & $2167 \pm 859^{b}$ & $1722 \pm 894^{\mathrm{b}}$ \\
\hline Monocytes $(\mu \mathrm{L})$ & $1901 \pm 790^{a}$ & $1547 \pm 704^{a}$ & $1257 \pm 915^{\mathrm{a}}$ & $1679 \pm 758^{a}$ \\
\hline Neutrophils $(\mu \mathrm{L})$ & $2510 \pm 824^{b}$ & $2535 \pm 1208^{\mathrm{b}}$ & $3425 \pm 1260^{\mathrm{ab}}$ & $4227 \pm 1309^{a}$ \\
\hline Eosinophils $(\mu \mathrm{L})$ & $224 \pm 124^{\mathrm{a}}$ & $212 \pm 185^{a}$ & $53 \pm 53^{b}$ & $35 \pm 34^{\mathrm{b}}$ \\
\hline PAS-GL $(\mu \mathrm{L})$ & $98 \pm 114^{\mathrm{a}}$ & $69 \pm 98^{\mathrm{a}}$ & $42 \pm 74.6^{\mathrm{a}}$ & $45 \pm 46^{\mathrm{a}}$ \\
\hline
\end{tabular}

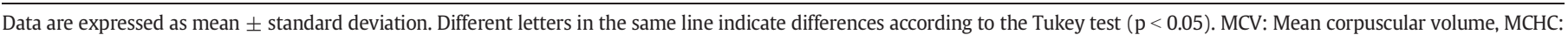
Mean corpuscular hemoglobin concentration, PAS-positive granular leukocytes (PAS-GL).

antiparasitic products (Boijink et al., 2015; Hashimoto et al., 2016: Huang et al., 2013; Ji et al., 2012; Steverding et al., 2005; Xiao-Feng et al., 2014; Zhang et al., 2013; Zhang et al., 2014; Zheng et al., 2015), since these could form an alternative to chemotherapeutic products.

In the in vitro trial of the present study, $100 \%$ mortality of A. spathulatus, M. boegeri and N. janauachensis exposed to $160 \mathrm{mg} / \mathrm{L}$ of the essential oil of $L$. alba (the lowest concentration used), occurred within $3 \mathrm{~h}$ of the exposure, while this only occurred among the parasites exposed to water or water + alcohol (controls) after $9 \mathrm{~h}$. Moreover, among the parasites exposed to 1289 and $2560 \mathrm{mg} / \mathrm{L}$ (which were the highest concentrations of the essential oil of $L$. alba used), $100 \%$ mortality occurred within $1 \mathrm{~h}$. On the other hand, Hashimoto et al. (2016) reported that $160 \mathrm{mg} / \mathrm{L}$ of the essential oil of Lippia sidoides caused complete in vitro mortality of Cichlidogyrus tilapiae, Cichlidogyrus thurstonae, Cichlidogyrus halli and Scutogyrus longicornis, from Oreochromis niloticus, within approximately $8 \mathrm{~min}$, while their higher concentration $(320 \mathrm{mg} / \mathrm{L}$ of the essential oil) caused $100 \%$ mortality within $2 \mathrm{~min}$. These authors also found that complete immobilization of these parasites in the groups exposed to water or water + DMSO occurred over a period of more than $4 \mathrm{~h}$. Therefore, these results show that there are different responses from different parasites to oils coming from congeneric species of Lippia.

For C. macropomum, all the concentrations of the essential oil of L. alba showed $100 \%$ in vitro efficacy against monogenoideans. However, this anthelmintic activity was dose-dependent and therefore, two concentrations of the essential oil of $L$. alba were tested as therapeutic baths. Likewise, an extract from Euphorbia fischeriana showed 87.3\% in vitro efficacy against Dactylogyrus vastator in Carassius auratus (Zhang et al., 2014). Although medicinal plants or their separate major chemical constituents have the advantage of low toxicity in comparison with chemotherapeutic products (Huang et al., 2013; Zhang et al., 2013; Zheng et al., 2015), the high concentrations obtained in in vitro trials cannot always be used in antiparasitic control and treatment among fish because of their toxicity (Hashimoto et al., 2016; Ji et al., 2012).

During therapeutic baths with the essential oil of $L$. alba, it has been observed that $C$. macropomum remains static because of the anesthetic effect of this oil (Azambuja et al., 2011; Cunha et al., 2010). Similar anesthetic effects from eugenol (Boijink et al., 2015) and the essential oil of L. sidoides (Hashimoto et al., 2016) have been reported for C. macropomum and $O$. niloticus, respectively. Consequently, only two low concentrations of the essential oil of $L$. alba could be used in the therapeutic baths for the in vitro trials ( 100 and $150 \mathrm{mg} / \mathrm{L}$ ), because of the toxicity of this essential oil and its anesthetic effect. However, since no studies evaluating the antiparasitic activity of $L$. alba have previously been published, the present study provides the first report of this activity for this medicinal plant.
In the in vivo trials on $C$. macropomum, all the fish specimens in the different treatments presented gills infected with $M$. boegeri, A. spathulatus, N. janauachensis and I. multifiliis. In the fish exposed to 100 and $150 \mathrm{mg} / \mathrm{L}$ of the essential oil of $L$. alba, for $30 \mathrm{~min}$, the efficacy of the treatment against I. multifiliis was $40.7 \%$ and $50.3 \%$, respectively. Bioactive compounds derived from Toddalia asiática have also shown similarly low in vivo efficacy against I. multifiliis, although the in vitro efficacy was 100\% (Xiao-Feng et al., 2014). However, Zheng et al. (2015) demonstrated reductions in the prevalence of $I$. multifilis ranging from $27.7 \%$ to $100 \%$ after exposure of the parasites to bioactive compounds derived from Costus speciosus, while the in vivo efficacy was only 16.7 and $26.7 \%$, for Ctenopharyngodon idella and C. auratus respectively. Moreover, among the fish of the present study exposed to $100 \mathrm{mg} / \mathrm{L}$ of the essential oil of $L$. alba, the efficacy against monogenoideans was low (14.0\%). Hashimoto et al. (2016) also found low efficacy (1.9\%) for $20 \mathrm{mg} / \mathrm{L}$ of the essential oil of $L$. sidoides against monogenoideans of Nile tilapia. On the other hand, exposure of C. auratus to extracts of Cinnamomum cassia, Lindera aggregata, Pseudolarix kaempferi, Caesalpinia sappan, Lysima chiachristinae, Cuscuta chinensis, Artemisia argyi and Eupatorium fortunei showed 100\% efficacy against Dactylogyrus intermedius (Huang et al., 2013; Ji et al., 2012).

In this study, fish exposed to 100 and $150 \mathrm{mg} / \mathrm{L}$ of the essential oil of L. alba for 30 min showed low efficacy against monogenoideans but also

Table 5

Mean alteration value (MAV) and histopathological alteration index (HAI) of the gills of Colossoma macropomum exposed to the essential oil of Lippia alba.

\begin{tabular}{|c|c|c|c|c|}
\hline \multicolumn{5}{|c|}{ After 30-min therapeutic bath } \\
\hline Treatments & $\mathrm{N}$ & MAV & HAI & $\begin{array}{l}\text { Severity of the lesions according } \\
\text { to the HAI }\end{array}$ \\
\hline Water & 6 & $1.2 \pm 0.4^{\mathrm{aA}}$ & $7.2 \pm 6.5^{\mathrm{aA}}$ & Normal functioning of the gills \\
\hline $\begin{array}{l}\text { Water }+ \\
\text { alcohol }\end{array}$ & 6 & $1.7 \pm 0.5^{\mathrm{aA}}$ & $12.5 \pm 8.0^{\mathrm{aA}}$ & $\begin{array}{l}\text { Mild to moderate damage to the } \\
\text { gills }\end{array}$ \\
\hline $100 \mathrm{mg} / \mathrm{L}$ & 6 & $2.2 \pm 0.8^{\mathrm{aA}}$ & $66.0 \pm 62.0^{\mathrm{bB}}$ & Severe alterations to the gills \\
\hline $150 \mathrm{mg} / \mathrm{L}$ & 6 & $2.3 \pm 0.5^{\mathrm{aA}}$ & $121.0 \pm 5.0^{\mathrm{cB}}$ & Irreparable damage to the gills \\
\hline \multicolumn{5}{|c|}{ After $24 \mathrm{~h}$ of recovery subsequent to therapeutic bath } \\
\hline Water & 6 & $1.5 \pm 0.5^{\mathrm{aB}}$ & $29.0 \pm 44.0^{\mathrm{aA}}$ & $\begin{array}{l}\text { Moderate to severe alterations to } \\
\text { the gills }\end{array}$ \\
\hline $\begin{array}{l}\text { Water }+ \\
\text { alcohol }\end{array}$ & 6 & $2.8 \pm 0.4^{\mathrm{aA}}$ & $118.0 \pm 4.0^{\mathrm{bB}}$ & Irreparable damage to the gills \\
\hline $100 \mathrm{mg} / \mathrm{L}$ & 6 & $2.5 \pm 0.5^{\mathrm{aA}}$ & $123.0 \pm 5.0^{\mathrm{bB}}$ & Irreparable damage to the gills \\
\hline $150 \mathrm{mg} / \mathrm{L}$ & 6 & $2.8 \pm 0.4^{\mathrm{aA}}$ & $126.0 \pm 2.0^{\mathrm{bB}}$ & Irreparable damage to the gills \\
\hline
\end{tabular}

The same lower-case letter in the same column indicates that there were no differences between the treatments, while upper-case letter in the same column indicates differences between the times, according to the Tukey test $(\mathrm{p}<0.05)$. 



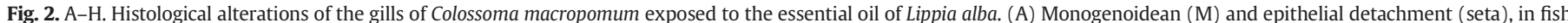

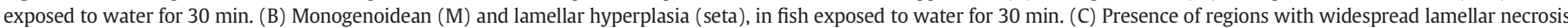

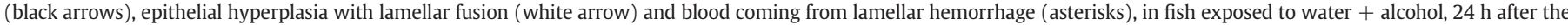

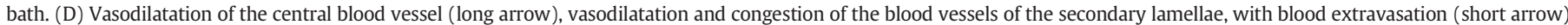

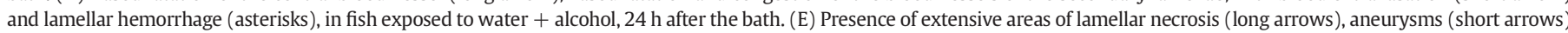

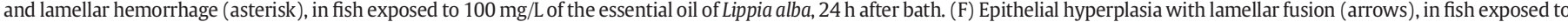

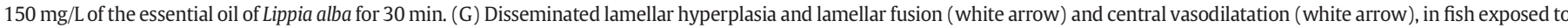

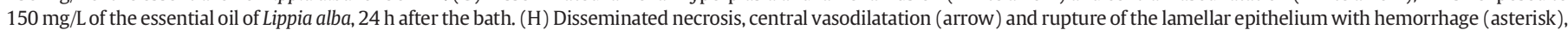
in fish exposed to $150 \mathrm{mg} / \mathrm{L}$ of the essential oil of Lippia alba, $24 \mathrm{~h}$ after the bath. 
there were severe structural alterations to the gills, which are organs that participate in respiration, osmoregulation and excretion in fish (Fiuza et al., 2011; Kumar et al., 2010). Moreover, intense parasitism by monogenoideans and by I. multifiliis was observed in all the treatments, which also influenced the tissue integrity of the gills. In fish exposed to water, the only occurrences were hyperplasia of the epithelium, fusion and rupture of the lamellar epithelium with hemorrhage, and epithelial detachment. These lesions were distributed in a dispersed manner across the gills, such that some areas had more lesions than others and there was no predominance of lesions in any specific area of this organ. Similar alterations have also been described in relations to parasitized specimens of Rachycentron canadum (GuerraSantos et al., 2012) and Piaractus brachypomus (Verján et al., 2001). However, in the fish exposed to water + alcohol, there were late lesions in the gill epithelium of $C$. macropomum, seen $24 \mathrm{~h}$ after the exposure. However, in fish exposed to the essential oil of $L$. alba, the severity of the gill lesions was directly proportional to the length of exposure and the concentration of this essential oil. $24 \mathrm{~h}$ after the baths, the alterations in the gills were more severe and irreparable among the fish treated with $150 \mathrm{mg} / \mathrm{L}$ of the essential oil of $L$. alba. Therefore, these structural alterations to the gills of $C$. macropomum were caused by the toxicity of the essential oil of $L$. alba and were boosted by the diluent of this essential oil. Similar action by different diluents has been described in relation to Heteropneustes fossilis exposed to an extract from Azadirachta indica (Kumar et al., 2010) and in relation to 0 . niloticus exposed to an extract from Eugenia uniflora (Fiuza et al., 2011).

In C. macropomum, after the baths with the essential oil of $L$. alba an increase in the plasma glucose levels was observed. This was also seen in fish exposed to water + alcohol, due to stress caused by the alterations in the gills (Barton and Iwama, 1991; Hashimoto et al., 2016). However, the RBC number and hematocrit percentage decreased because of the lesions in the gills (especially because of hemorrhages), while the MCHC and total thrombocytes number increased because of attempts to return to homeostasis and hemostasis. Similar studies on 0 . niloticus have also reported increased glucose levels after a 10min bath with $20 \mathrm{mg} / \mathrm{L}$ of the essential oil of L. sidoides, caused by stress. On the other hand, increased RBC number and hematocrit percentage, with reduced total thrombocytes number, has been described (Hashimoto et al., 2016). Furthermore, in the fish exposed to the essential oil of $L$. alba, the WBC number decreased because of reductions in the number of lymphocytes and eosinophils, while in the fish exposed to $150 \mathrm{mg} / \mathrm{L}$ of the essential oil of $L$. alba, there was an increase in the neutrophil number, in response to the severity of the alterations to the gills (Ranzani-Paiva et al., 2013). Similar responses by neutrophil number, which is the organism's first line of defense against infections and tissue lesions (Ranzani-Paiva et al., 2013; Tavares-Dias et al., 1999), have also been reported for 0 . niloticus exposed to the essential oil of $L$. sidoides, but without any alteration to the leukocytes count (Hashimoto et al., 2016).

In conclusion, the essential oil of $L$. alba demonstrated in vitro antiparasitic activity against gill parasites of tambaqui, but its in vivo antiparasitic efficacy was relatively boosted by the diluent of this oil, as has also been seen in other studies that used other, different diluents (Hashimoto et al., 2016; Steverding et al., 2005). Moreover, the essential oil of $L$. alba caused blood alterations and severe structural alterations to the gills of the fish, which were irreversible $24 \mathrm{~h}$ after the exposure. Consequently, the essential oil of $L$. alba cannot be recommended for antiparasitic control and treatment, except if used in a manner that reduces its toxicity and deleterious effects on the gills of fish. Therefore, since phytotherapeutic products are promising sources of the main bioactive agents that may be useful in relation to fish farming, studies should be conducted in order to investigate the best way of making therapeutic use of this essential oil among fish (e.g. using nanotechnology), as an antiparasitic agent with greater effectiveness and less toxicity.

\section{Acknowledgments}

The authors thank the National Council for Scientific and Technological Development (Conselho Nacional de Desenvolvimento Científico e Tecnológico, CNPq) for financial support (\#472054/2013-9) and FAPEAM (\#PPP -392/2012). M. Tavares-Dias was also supported by a Research fellowship from CNPq.

\section{References}

Azambuja, C.R., Mattiazzi, J., Riffel, A.P.K., Finamor, I.A., Garcia, L.O., Heldwein, C.G., Heinzmann, B.M., Baldisserotto, B., Pavanato, M.A., Llesuy, S.F., 2011. Effect of the essential oil of Lippia alba on oxidative stress parameters in silver catfish (Rhamdia quelen) subjected to transport. Aquaculture 319, 156-161.

Barton, B.A., Iwama, G.K., 1991. Physiological changes in fish from stress in aquaculture with emphasis on the response and affects of corticosteroids. Annu. Rev. Fish Dis. 1, 3-26.

Boijink, C.L., Miranda, W.S.C., Chagas, E.C., Dairiki, J.K., Inoue, L.A.K.A., 2015. Anthelmintic activity of eugenol in tambaquis with monogenean gill infection. Aquaculture 438, 138-140.

Bush, A.O., Lafferty, K.D., Lotz, J.M., Shostack, A.W., 1997. Parasitology meets ecology on its own terms: Margolis et al. revisited. J. Parasitol. 83 (4), 575-583.

Cohen, S.C., Justo, M.C.N., Kohn, A., 2013. South American monogenoidea parasites of fishes, amphibians and reptiles. Rio de Janeiro. Oficina de Livros $662 \mathrm{pp}$.

Cunha, M.A., Barros, F.M.C., Garcia, L.O., Veeck, A.P.L., Heinzmann, B.M., Loro, V.L., Emanuelli, T., Baldisserotto, B., 2010. Essential oil of Lippia alba: a new anesthetic for silver catfish, Rhamdia quelen. Aquaculture 306, 403-406.

Eiras, J.C., Takemoto, R.M., Pavanelli, G.C., 2006. Métodos de estudos e técnicas laboratoriais em parasitologia de peixes. Editora UEM, Maringá 173 pp.

Escobar, P., Leal, S.M., Herrera, L.V., Martinez, J.R., Stashenko, E., 2010. Chemical composition and antiprotozoal activities of Colombian Lippia spp essential oils and their major components. Men. Inst. Oswaldo Cruz. 105 (2), 184-190.

Fabri, R.L., Nogueira, M.S., Moreira, J.R., Bouzada, M.L.M., Scio, E., 2011. Identification of antioxidant and antimicrobial compounds of Lippia species by bioautography. J. Med. Food 14 (7/8), 840-846.

Fiuza, T.S., Silva, P.C., Paula, J.R., Tresvenzol, L.M.F., Souto, M.E.D., Sabóia-Morais, S.M.T., 2011. Análise tecidual e celular das brânquias de Oreochromis niloticus L. tratadas com extrato etanólico bruto e frações das folhas da pitanga (Eugenia uniflora L.) Myrtaceae. Rev. Brasil. Pl. Med. 13 (4), 389-395.

Guerra-Santos, B., Albinati, R.C.B., Moreira, E.L.T., Lima, F.W.M., Azevedo, T.M.P., Costa, D.S.P., Medeiros, S.D.C., Lira, A.D., 2012. Parâmetros hematológicos e alterações histopatológicas em bijupirá (Rachycentron canadum Linnaeus, 1766) com amyloodiniose. Pesqui. Vet. Bras. 32 (11), 1184-1190.

Haldar, S., Kar, B., Dolai, N., Kumar, R.B.S., Behera, B., Haldar, P.K., 2012. In vivo antinociceptive and anti-inflammatory activities of Lippia alba. Asian Pacific. J. Trop. Dis. S667-S670.

Hashimoto, G.S.O., Neto, F.M., Ruiz, M.L., Achille, M., Chagas, E.C., Chaves, F.C.M., Martins, M.L., 2016. Essential oils of Lippia sidoides and Mentha piperita against monogenean parasites and their influence on the hematology of Nile tilapia. Aquaculture 450, 182-186.

Huang, A.G., Yi, Y.L., Ling, F., Lu, L., Zhang, Q.Z., Wang, G.X., 2013. Screening of plant extracts for anthelmintic activity against Dactylogyrus intermedius (Monogenea) in goldfish (Carassius auratus). Parasitol. Res. 112, 4065-4072.

Ji, J., Lu, C., Kang, Y., Wang, G.X., Chen, P., 2012. Screening of 42 medicinal plants for in vivo anthelmintic activity against Dactylogyrus intermedius (Monogenea) in goldfish (Carassius auratus). Parasitol. Res. 111, 97-104.

Kumar, A., Prasad, M.R., Srivastava, K., Tripathi, S., Srivastav, A.K., 2010. Branchial histopathological study of catfish Heteropneustes fossilis following exposure to purified neem extract, azadirachtin. World J. Zool. 5 (4), 239-243.

Mamun-Or-Rashid, A.N.M., Sem, M.K., Jamal, M.A.H.M., Nasrin, S., 2013. A comprehensive ethno-pharmacological review on Lippia alba M. Intern. J. Biom. Mat. Res. 1 (1), 14-20.

Martins, M.L., Moraes, F.R., Fujimoto, R.Y., Nomura, D.T., Fenerick Jr., J., 2002. Respostas do híbrido tambacu (Piractus mesopotamicus Holmberg, 1887 macho X Colossoma macropomum Cuvier, 1818 fêmea) a estímulos simples ou consecutivos de captura. B. Inst. Pesca. 28 (2), 195-204.

Nogueira, M.A., Diaz, G., Sakumo, L., 2007. Caracterização química e atividade biológica do óleo essencial de Lippia alba cultivada no Paraná. J. Anim. Plant. Sci. 28, 273-278.

Oliveira, D.R., Leitão, G.G., Santos, S.S., Bizzo, H.R., Lopes, D., Alviano, C.S., Alviano, D.S., Leitão, S.G., 2006. Ethnopharmacological study of two Lippia species from Oriximiná. J. Ethnopharmacol. 108, 103-108.

Pinheiro, D.A., Cavero, B.A.S., Vargas, L., Braccini, G.L., Yoshioka, E.T.O., Oliveira, M.S.B., Tavares-Dias, M., 2015. Performance, parasitic infections, hematology and hepatic histology of Colossoma macropomum (tambaqui) fed on homeopathic product. Afr. J. Pharm. Pharmacol. 9 (4), 82-90.

Poleksic, V.. Mitrovic-Tutundzic, V. 1994. Fish gills as a monitor of sublethal and chronic effects of pollution. In: Muller, R., Lloyd, R. (Eds.), Sublethal and Chronic Effects of Pollutants on Freshwater Fish. Fishing News Books, Oxford, pp. 339-352.

Ranzani-Paiva, M.J.T., Padua, S.B., Tavares-Dias, M., Egami, M.I., 2013. Métodos para análises hematológicas em peixes. EDUEM, Maringá, São Paulo. 135p.

Schwaiger, J., Wanke, R., Adam, S., Pawert, M., Honnen, W., Triebskorn, R., 1997. The use of histopathological indicators to evaluate contaminant-related stress in fish. J. Aquat. Ecosyst. Stress. Recover. 6, 75-86. 
Steverding, D., Morgan, E., Tkaczynski, P., Walder, F., Tinsley, R., 2005. Effect of Australian tea tree oil on Gyrodactylus spp., infection of the three-spined stickleback Gasterosteus aculeatus. Dis. Aquat. Org. 66, 29-32.

Tavares, I.B., Momenté, V.G., Nascimento, d.I.R., 2011. Lippia alba: estudos químicos, etnofarmacológicos e agronômicos. Rev. Brasil. Tecn. Apl. Ciên. Agr. 4, 204-220.

Tavares-Dias, M., Sandrin, E.F.S., Campos, F.E., 1999. Hematological characteristics of tambaqui Colossoma macropomum Cuvier (Osteichthyes, Characidae) under intensive system. II. Leukocytes. Revta Brasil. Zoology 16, 175-184.

Verján, N., Iregui, C.A., Rey, A.L., Donado, P., 2001. Sistematización y caracterización de las lesiones branquiales de la cachama blanca (Piaractus brachypomus) de cultivo clínicamente sana: algunas interacciones hospedador-patógeno-ambiente. Revista AquaTIC n.15.

Xiao-feng, S., Qin-feng, M., Yuan-huan, K., Yu, B., Yun-hang, G., Wei-li, W., Ai-dong, Q., 2014. Isolation of active compounds from methanol extracts of Toddalia asiatica against Ichthyophthirius multifiliis in goldfish (Carassius auratus). Vet. Parasitol. 199, 250-254.

Zhang, Q., Xu, D.H., Klesius, P.H., 2013. Evaluation of an antiparasitic compound extracted from Galla chinensis against fish parasite Ichthyophthirius multifilis. Vet. Parasitol. 198 45-53.

Zhang, X.P., Li, W.X., Ai, T.S., Zou, H., Wu, S.G., Wang, G.T., 2014. The efficacy of four common anthelmintic drugs and traditional Chinese medicinal plant extracts to control Dactylogyrus vastator (Monogenea). Aquaculture 420-421, 302-307.

Zheng, W., Yan, C., Zhang, Y., Li, Z.-h., Li, Z., Li, X., Wang, X., Chen, W., Yu, X., 2015. Antiparasitic efficacy of gracillin and Zingibernsis newsaponin from Costus speciosus (Koen ex. Retz) Sm. against Ichthyophthirius multifilis. Parasitology 142, 473-479. 